Research, part of a Special Feature on Bridging Conservation and Development in Latin America and Africa: Changing Contexts, Changing Strategies

\title{
Empowering Local People through Community-based Resource Monitoring: a Comparison of Brazil and Namibia
}

\author{
$\underline{\text { Pedro de Araujo Lima Constantino }}{ }^{1,2}, \underline{\text { Henrique Santiago Alberto Carlos }}^{3}, \underline{\text { Emiliano Esterci Ramalho }}^{1,4}, \underline{\text { Luke Rostant }}^{5}$, \\ $\underline{\text { Carlos Eduardo Marinelli }}^{6}$, Davi Teles $^{3}$, Sinomar Fonseca Fonseca-Junior $^{3}, \underline{\text { Rômulo Batista Fernandes }}^{3}$ and $\underline{\text { João Valsecchi }}$ \\ $\frac{\text { Cart }}{4}$
}

ABSTRACT. Biological resource monitoring systems are implemented in many countries and often depend on the participation of local people. It has been suggested that these systems empower local participants while promoting conservation. We reviewed three wildlife monitoring systems in indigenous lands and sustainable development reserves in Brazilian Amazonia and one in Namibian Caprivi conservancies, analyzing the strategies adopted and conditions that facilitated local empowerment, as well as potential impacts on conservation. This provided insights into potential avenues to strengthen empowerment outcomes of monitoring systems in Latin America and Africa. We assessed four dimensions of empowerment at individual and community scales: psychological, social, economic, and political. The conditions that facilitated local empowerment included the value of natural resources, rights to trade and manage resources, political organization of communities, and collaboration by stakeholders. The wide range of strategies to empower local people included intensifying local participation, linking them to local education, feeding information back to communities, purposefully selecting participants, paying for monitoring services, marketing monitored resources, and inserting local people into broader politics. Although communities were socially and politically empowered, the monitoring systems more often promoted individual empowerment. Marketing of natural resources promoted higher economic empowerment in conservancies in Namibia, whereas information dissemination was better in Brazil because of integrated education programs. We suggest that practitioners take advantage of local facilitating conditions to enhance the empowerment of communities, bearing in mind that increasing autonomy to make management decisions may not agree with international conservation goals. Our comparative analysis of cases in Latin America and Africa allows for a greater understanding of the relationships between resource monitoring systems, local empowerment, and conservation.

Key Words: Acre; Amazônas; Caprivi; community participation; decentralization; indigenous people; protected area; wildlife management

\section{INTRODUCTION}

Tropical countries have adopted different approaches to decentralize and democratize biological resource management (Larson and Soto 2008). Protected areas where people have collective management rights are one of these approaches, decentralizing power while merging conservation and development goals (Brown 2002). Biological resource monitoring systems have also been implemented to understand the consequences of contemporary species loss (Scholes et al. 2008), particularly for common-pool resources in these protected areas (Danielsen et al. 2010a). These systems increasingly depend upon the involvement of local people to improve their efficiency (Danielsen et al. 2005, 2011) but can fail if information is not useful to local communities (Lawrence and Elphick 2002, Danielsen et al. 2003). The intensification of local participation in biological resource monitoring systems introduces social, political, and cultural dimensions to monitoring systems that go beyond data collection (Lawrence 2006, Stuart-Hill et al. 2006, Danielsen et al. 2010a, Lindenmayer and Likens 2010) and has potential implications for local empowerment (Moller et al. 2004, Lawrence et al. 2006, Chambers 2007).

Participatory monitoring is a conservation strategy that enables empowerment to be more effective and lasting than participatory methods with a shorter life-span (Danielsen et al. 2003, Rijsoort and Jinfeng 2005, Stringer et al. 2006, Cundill and Fabricius 2009). However, local participation alone does not guarantee empowerment because it depends upon the local context and the strategies employed when the monitoring program is implemented (Danielsen et al. 2009). Recent attempts to understand the relationships between resource monitoring and local empowerment in the tropics indicate that local participation promotes empowerment in diverse ways (Lawrence 2006, Garnett et al. 2009, Danielsen et al. 2010a). As more communities are tasked with decentralizing resource management (United Nations Environment Program 2001), and conservation strategies seek to include local empowerment (Brown 2002, Kilbane Gockel 
and Gray 2009, Lele et al. 2010), a deeper understanding of the empowerment outcomes of participatory programs is required (Danielsen et al. 2009, DeCaro and Stokes 2008).

We contribute to this debate by investigating the relationship between participatory biological resource monitoring and local empowerment at different scales and dimensions, comparing it across different regions. We describe three new initiatives in Brazilian Amazonia and revisit one initiative in the Namibian Caprivi in southern Africa, analyzing the strategies used in the monitoring systems and external conditions that facilitated local empowerment. Finally, we discuss how monitoring systems could improve local empowerment in Latin America and Africa, as well as the potential consequences of such empowerment for conservation.

\section{Empowerment: a multidimensional and multiscalar concept}

Concepts of power may vary according to the necessity to explore and explain diverse contexts and may be dependent on the actors involved in power relationships (Eyben et al. 2006). Therefore, practical working definitions can be applied in study cases. Because we deal here mainly with "informal power that is dispersed through society and operates in all relationships" (Eyben et al. 2006:2), we adopted the broad definition of empowerment as "a participatory, developmental process through which marginalized or oppressed individuals and groups gain greater control over their lives and environment, acquire valued resources and basic rights, and achieve important life goals and reduced societal marginalization" (Maton 2008:5). Empowerment is simultaneously a consequence and a process of development at individual or community scales (Rappaport 1987) allowed by the powerful or conquered by the powerless (Luttrel et al. 2009). At the scale of an individual, empowerment represents one's capacity to gain control over personal life and to promote changes in power structures that improve one's well-being (Zimmerman et al. 1992). At the scale of the community, empowerment refers to the processes that make a community gain collective power in relation to a previous state (Eyben et al. 2006). Whether at the individual or community scale, empowerment can occur in different dimensions (Speer and Hughey 1995, Sofield 2003, Manton 2008). These dimensions include psychological (e.g., development of pride, selfesteem, the feeling of freedom of choice), economic (e.g., financial resources, control of subsistence resources), social (e.g., women rights, education, improvement of local organizations, increased social capital), and political (e.g., participation in decisions, development of leadership, increased local governance over natural resources). Although separated into these categories to facilitate our analysis, empowerment in one dimension or scale is not independent from others (Saegert and Winkel 1996, Lawrence 2006). Social and political empowerment, for example, may be simultaneously achieved by an individual and, at the same time, influence community empowerment (Samah and Aref 2011).

We recognize that a gradient of empowerment may occur, with individual psychological empowerment in opposition to political community empowerment (Arnstein 1969, Rocha 1997). The former could be considered a simpler scale and dimension because of its restricted transformative power, whereas the latter could be considered a more complex empowerment because of its lasting and more transformative characteristics (Kapoor 2002). We also acknowledge that there are situations in which empowerment may not fit into this model and transformative changes may occur because of power changes at simpler scales and dimensions (Lawrence 2006).

\section{METHODS}

\section{Description of the community-based monitoring case studies}

We briefly describe the four community wildlife monitoring systems from Latin America and southern Africa (Table 1). Details may be found in their associated publications. Three systems were implemented in Brazilian Amazonia protected areas (two of which are Sustainable Development Reserves): hunting in indigenous lands in Acre state (HIL), biodiversity and natural resource use in Amazonas protected areas (ProBUC), and the fauna monitoring system of the Mamirauá Sustainable Development Institute (SMUF). The fourth, the event book system (EBS), was established in Namibian Caprivi Conservancies in Africa. The four monitoring systems use sample methods and quantitative indicators widely reported in the scientific literature (e.g., Peres 2000, StuartHill et al. 2005, Rist et al. 2010) and have been adapted to their local contexts given the monitoring targets.

\section{Monitoring of hunting in indigenous lands in Acre state (HIL)}

The system for monitoring wildlife hunting in indigenous lands evaluates the effects of wildlife use by indigenous people and was co-designed by indigenous leaders, the local nongovernmental organization (NGO) Comissão Pró-Índio do Acre, The Nature Conservancy staff, and protected areas managers. The system was implemented in 2004 as a component of the education program led by Comissão PróÍndio do Acre for indigenous agroforestry agent representatives selected by indigenous communities (hereafter monitors), and paid for by the Acre state government, which is responsible for leading environmental discussions with communities and external institutions. Forty-five monitors were responsible for mobilizing their communities to record, analyze, and interpret hunting data. The monitoring tools and methods were adapted to daily activities, demanding little additional labor. Monitors reported daily hunting activities 
Table 1. Characteristics of biological resource monitoring systems in Brazilian Amazonia and Namibian Caprivi.

\begin{tabular}{|c|c|c|c|c|}
\hline \multirow[b]{2}{*}{ Characteristic } & \multicolumn{4}{|c|}{ Resource monitoring system } \\
\hline & $\begin{array}{l}\text { Hunting in Indigenous } \\
\text { Lands (HIL) }\end{array}$ & $\begin{array}{c}\text { Biodiversity and Natural Resources } \\
\text { Monitoring Use Program of } \\
\text { Amazonas Protected Areas } \\
\text { (ProBUC) }\end{array}$ & $\begin{array}{l}\text { Fauna Monitoring System of the } \\
\text { Mamirauá Institute (SMUF) }\end{array}$ & Event Book System (EBS) \\
\hline Location & Brazilian Amazonia & Brazilian Amazonia & Brazilian Amazonia & Namibia Caprivi \\
\hline Region & Acre state & Amazonas state & Amazonas state & Namibia \\
\hline $\begin{array}{l}\text { Protected Area/IUCN } \\
\text { category }\end{array}$ & $\begin{array}{l}\text { Indigenous Lands (IL), } \\
\text { mainly Kaxinawá and } \\
\text { Katukina }\end{array}$ & $\begin{array}{c}\text { State Protected Areas, mainly } \\
\text { Sustainable Development Reserve } \\
\text { (SDR) Uacari }\end{array}$ & $\begin{array}{c}\text { Sustainable Development } \\
\text { Reserve (SDR) Mamirauá and } \\
\text { Amanã }\end{array}$ & Conservancies \\
\hline Management regime & $\begin{array}{l}\text { Federal land; indigenous } \\
\text { communities have } \\
\text { exclusive subsistence use } \\
\text { rights }\end{array}$ & $\begin{array}{c}\text { State land; communities have } \\
\text { concession for subsistence use; co- } \\
\text { managed with government } \\
\text { environmental agency and organized } \\
\text { civil society }\end{array}$ & $\begin{array}{l}\text { State land; communities have } \\
\text { concession for subsistence use; } \\
\text { co-managed with government } \\
\text { environmental agency and } \\
\text { Mamirauá Sustainable } \\
\text { Development Institute }\end{array}$ & $\begin{array}{l}\text { Federal land; communities } \\
\text { have use rights }\end{array}$ \\
\hline $\begin{array}{l}\text { Approximate extent of } \\
\text { monitoring system } \\
\text { (number of protected } \\
\text { areas) }\end{array}$ & $6243 \mathrm{~km}^{2}$ (8 IL) & $6330 \mathrm{~km}^{2}$ (1 SDR) & $34,624 \mathrm{~km}^{2}$ (2 SDR) & $\begin{array}{l}149,829 \mathrm{~km}^{2}(71 \\
\text { Conservancies })\end{array}$ \\
\hline $\begin{array}{l}\text { Average community } \\
\text { population (number of } \\
\text { communities) }\end{array}$ & $65(45)$ & $40(6)$ & $74(10)$ & $3784(59)$ \\
\hline $\begin{array}{l}\text { Biological resources } \\
\text { monitored }\end{array}$ & Game species and harvest & $\begin{array}{l}\text { Game species and harvest, plant } \\
\text { species extractive production }\end{array}$ & Game species and harvest & $\begin{array}{l}\text { Game species and harvest, } \\
\text { craft resources and sales, } \\
\text { rainfall }\end{array}$ \\
\hline $\begin{array}{l}\text { Importance of } \\
\text { monitored resource to } \\
\text { communities }\end{array}$ & Main meat source & $\begin{array}{l}\text { Game commonly used; manioc flour } \\
\text { and fish are the main income }\end{array}$ & Main meat source & $\begin{array}{l}\text { Economic benefits from } \\
\text { crafts plant products and } \\
\text { wildlife; food supplemented } \\
\text { by wildlife }\end{array}$ \\
\hline $\begin{array}{l}\text { Stakeholders } \\
\text { participating }\end{array}$ & $\begin{array}{c}\text { Indigenous communities, } \\
\text { Comissão Pró-Índio do } \\
\text { Acre (local } \\
\text { nongovernmental } \\
\text { organization), The Nature } \\
\text { Conservancy, Gordon and } \\
\text { Betty Moore Foundation, } \\
\text { independent researcher }\end{array}$ & $\begin{array}{l}\text { Ribeirinho communities, local } \\
\text { associations, municipal governments, } \\
\text { Centro Estadual de Unidades de } \\
\text { Conservação (state environmental } \\
\text { agency), University of Amazonas, } \\
\text { Instituto Nacional de Pesquisas } \\
\text { Amazônicas (research institute), } \\
\text { Federal government (ARPA } \\
\text { Program), Gordon and Betty Moore } \\
\text { Foundation }\end{array}$ & $\begin{array}{c}\text { Ribeirinho communities, } \\
\text { Mamirauá Sustainable } \\
\text { Development Institute (research } \\
\text { institute), Gordon and Betty } \\
\text { Moore Foundation }\end{array}$ & $\begin{array}{l}\text { Namibian Association of } \\
\text { CBNRM Support } \\
\text { Organizations, Ministry of } \\
\text { Environment and Tourism, } \\
\text { World Wildlife Fund, } \\
\text { University of Namibia }\end{array}$ \\
\hline $\begin{array}{l}\text { Institution requesting } \\
\text { monitoring system }\end{array}$ & $\begin{array}{l}\text { The Nature Conservancy, } \\
\text { Gordon and Betty Moore } \\
\text { Foundation }\end{array}$ & $\begin{array}{c}\text { Amazonas state government, Federal } \\
\text { government through the ARPA } \\
\text { program }\end{array}$ & $\begin{array}{l}\text { Mamirauá Sustainable } \\
\text { Development Institute }\end{array}$ & $\begin{array}{l}\text { World Wildlife Fund, } \\
\text { Integrated Rural } \\
\text { Development and Nature } \\
\text { Conservancy, Ministry of } \\
\text { Environment and Tourism }\end{array}$ \\
\hline $\begin{array}{l}\text { Main objective of } \\
\text { monitoring system }\end{array}$ & $\begin{array}{l}\text { Education and } \\
\text { management }\end{array}$ & $\begin{array}{l}\text { Management information and } \\
\text { livelihood improvement }\end{array}$ & $\begin{array}{l}\text { Management information and } \\
\text { scientific research }\end{array}$ & $\begin{array}{l}\text { Management of stochastic } \\
\text { events }\end{array}$ \\
\hline
\end{tabular}

using simple indicators such as number, species, and weight of hunted animals (Constantino et al. 2008, Constantino 2010; Table 1), which allowed inferences of wildlife harvest and availability (Jerozolimski and Peres 2003, Fa and Brown 2009). Comissão Pró-Índio do Acre and associate scientists provided technical support in the recording and analysis phases through the education program. This framework did not initially guarantee information quality, but maintained the program's empowerment objective. Because collaboration with external researchers created new ways for monitors to analyze the data, some villages started using monitoring information for local management (Constantino et al. 2008). Some monitors replicated the education model in village schools, using monitoring tools and data to teach diverse disciplines, and involved community members in the analysis and interpretation of monitoring results. Additionally, whereas some monitors set a series of community meetings to discuss wildlife monitoring and management, others requested training in new monitoring techniques (i.e., line transects) for gathering supplementary information. Regionally, monitoring information oriented conservation policy by updating the state ecological-economic zoning (Chaves et al. 2012). Monitoring 
continued in most villages despite the fact that funding stopped three years after project initiation.

\section{Biodiversity and natural resource use monitoring program for Amazonas protected areas (ProBUC)}

ProBUC was developed by the Amazonas state government Center for Protected Areas as a community-based monitoring system based on three main principles (Marinelli et al. 2007, Ferraz et al. 2008, Fonseca Junior et al. 2011): (1) researchers, government technicians, and local people must participate in all monitoring phases; (2) results must be applicable to local resource management; (3) the system and capacity building must be sustainable over the long term. Monitors were selected and trained based on interest and community approval, but women were prioritized for participating in some monitoring protocols. Further adaptation of the monitoring tools allowed illiterate community members to participate. Data collection began in the Uacari Sustainable Development Reserve in 2007 and was conducted exclusively by paid monitors. Communities selected the monitoring targets based on the identity and availability of resources harvested locally such as medium and large terrestrial game and turtles, as well as fish and plant extractive production. The quantitative indicators were simple, e.g., the number and species of animals harvested and observed in linear transects, fruit and timber production, and number of turtle nests (Andrade et al. 2005, Fonseca Junior et al. 2011; Table 1). Additional qualitative indicators were adopted to improve the management system description such as the harvesting technique. Community members and leaders participated in data analysis and program evaluation at periodic meetings for result feedback; the continuous training and discussions allowed the development of individual skills related to natural resource management and communication in wider debates. Monitors often represented their communities in discussions with municipal and state government to plan the management of the Uacari Sustainable Development Reserve and its vicinity. Moreover, the staff of the Center for Protected Areas and the communities also planned and executed a socialization strategy called Médio Juruá River Ecological Games, an annual cultural, educational, and recreational event that involved all communities of the Uacari Sustainable Development Reserve and their guests. Although focused on monitoring and conservation, the discussions during this event were not restrictive, allowing for strengthened internal social ties and community insertion in the municipal political agenda. With ProBUC's consolidation and the development of reciprocal trust between the Center for Protected Areas staff, monitors, and communities, more local people requested participation in ProBUC. This achievement was possible because of the constant presence of the Center for Protected Areas local staff and their genuine emotional involvement in the program, both of which fostered the emergence of reciprocal respect and a sense of group responsibility.
Fauna monitoring system of the Mamiraua Sustainable Development Institute (SMUF)

The Mamirauá Sustainable Development Institute, an organization of the civil society supported by the Brazilian Ministry of Science and Technology, created SMUF in 2002. The scientific objectives of SMUF were to quantify game harvest by communities, collecting data on all animals hunted in the selected communities (usually medium and large bodied vertebrates; Table 1), and describing the reproductive biology of species most frequently hunted in the Mamirauá and Amanã Sustainable Development Reserves (Amaral 2005). It was conceived as a research tool and designed in partnership with riverine communities in both reserves. The ultimate goal was to investigate whether hunting in the monitored communities was sustainable at current rates and to evaluate the viability of commercial harvest within the reserves (Valsecchi 2012). SMUF has monitored 10 communities since its designing phase, six in Mamirauá and four in Amanã. Data are collected by trained residents of each community hired by the Mamirauá Sustainable Development Institute to interview hunters. Monitor's salaries are under the same payment system as researchers. Monitors participate in ongoing capacitybuilding courses to guarantee data quality. Collaboration between researchers, monitors, and other community members is essential for SMUF to function given that access to hunting data is contingent upon hunters' willingness to share the information (Valsecchi and Amaral 2009). Monitoring results are presented and discussed annually with participating communities and have influenced management strategies for game species present in the Sustainable Development Reserves' management plans.

The event book system, Caprivi, Namibia (EBS)

In 1996, landmark legislation gave communities rights to wildlife and other natural resources, conditional on the capacity to manage them sustainably once they formed a common property institution called a conservancy (Jones and Murphree 2001). It was decided that communities should lead monitoring efforts because they were the ones responsible for management. EBS was designed collaboratively, by supporting NGOs, governments, and community representatives, as a management-oriented monitoring system for communities to act in response to stochastic events (StuartHill et al. 2005). Communities decide what to monitor and who will monitor using modular monitoring tools developed together with the supporting NGO; technicians provide assistance only when requested. Communities are trained by NGOs on how to use the modules, which include monitoring of wildlife, rainfall, and resources for craft-making (Table 1). Data collection and analysis are undertaken locally by conservancy members, and all information remains within the conservancy. Results are collated into monthly and yearly reporting charts, which are used by the supporting NGOs to report progress to the Ministry of Environment and Tourism 
and to conservancy donors (Rostant 2011). The accuracy of the information is audited on a biannual basis by the conservancy's facilitating NGO by working through the data with the conservancy management and data collectors to ensure they understand when mistakes have been made. Local managers use the information to help mitigate human-wildlife conflict, market the conservancies, develop craft-making skills, and sustainably manage craft resources. The management committee reports information back to the communities through village representatives and at annual meetings (Rostant 2011). Through participation in EBS, conservancies better engage with external agencies to negotiate natural resource use.

\section{Data collection and analysis}

Information on local empowerment was obtained using different methods, depending on the monitoring system, which allowed for analysis of different scales and dimensions. The coordinators, staff members, and associated researchers of each monitoring system, including the authors of this paper, conducted opportunistic surveys with monitors, community leaders, and representatives of grassroots organizations using different tools such as questionnaires, semi-structured interviews, and focal groups and debates on workshops and meetings held with representatives of the communities (IX International Congress of Wildlife Management in Amazonia, http://www.ixcimfauna-bol.museonoelkempff.org), as well as, and most significantly, personal observations. We qualitatively analyzed and compared the social-ecological conditions existing when systems were implemented that facilitated local empowerment (e.g., rights to manage the monitored resource, community political organization and leadership presence) and discussed how the strategies adopted by the monitoring systems (e.g., intensifying local participation, payment for monitoring services) resulted in local empowerment at the individual and community scales and psychological, economic, social, and political dimensions. During a series of focal group meetings, the coordinators, staff, and researchers of the monitoring systems qualitatively evaluated the relative importance of these strategies for local empowerment according to a four-point scale, where 0 indicates that the strategy was adopted but had no importance, and 3 indicates that the strategy was highly important for local empowerment. Finally, the same group of professionals scored each case study with respect to empowerment at both individual and community scales and the different dimensions of empowerment on a four-point scale, where 0 indicates that local empowerment was lowest, and 3 indicates that local empowerment was highest. The score values attributed to the empowerment strategies and empowerment scales and dimensions are relative to a comparison within and across only the four monitoring systems at the time they were analyzed; we thus acknowledge that these scores could change. Although we consider this method suitable for our purposes because we compared and contrasted our intimate experiences of these four monitoring systems, the numerical scale applied may not be representative of the range of potential empowerment outcomes for all monitoring systems and must be considered solely in the context of these monitoring systems and our experiences with them.

We finish by comparing the empowerment processes and outcomes promoted by monitoring systems from the two continents, indicating potential improvements.

\section{RESULTS}

Four main facilitating conditions for empowerment were identified in all case studies. These were the value of biological resources to local people, community rights to manage these resources, community political organization and leadership, and collaboration by stakeholders.

Local people were empowered through the adoption of eight main strategies in the four monitoring systems (Table 2). Overall, the strategies considered most important in promoting local empowerment were the intensification of local participation in the monitoring phases and the process of participant selection; these were the most common and extensively explored strategies. EBS was the only system using the marketing of monitored resources to empower locals, but it did not have any formal strategy to link the system with local education. The Brazilian systems, in turn, adopted education strategies, but only HIL fully explored this. These strategies had limited overall importance in promoting empowerment because they were not widely adopted and were not the focus of most systems.

Monitors from all monitoring systems were paid for their services, but this strategy was considered most important to local empowerment only by SMUF. The high importance of this strategy given by SMUF in relation to other empowerment strategies represents its main focus on science and conservation, being less oriented to social development and community empowerment. ProBUC also considered the feedback of information and results very relevant to empowering local people in Uacari Sustainable Development Reserve in Amazonas. The ability of monitoring results to inform larger policies and to promote community insertion in external politics were more profound in the Namibian than in the Brazilian contexts (Table 2).

These strategies allowed local empowerment to occur at the individual and community scales and in the psychological, social, economic, and political dimensions (Table 3). Overall, the systems were more capable of empowering individuals than communities, with EBS having the highest overall score and SMUF the lowest. Most of the programs empowered local people psychologically more than in any other dimension, except for SMUF and EBS, which were able to promote economic empowerment more than any other dimension. In 
Table 2. Strategies used to promote local empowerment. Numbers represent the authors' evaluation of the strategy's level of importance for local empowerment using a four-point scale, with 3 the highest and 0 the lowest degree of importance. A dash indicates that the strategy was not employed in the system.

\begin{tabular}{|c|c|c|c|c|c|}
\hline \multirow[b]{2}{*}{ Empowerment strategy } & \multicolumn{4}{|c|}{ Resource monitoring system } & \multirow[b]{2}{*}{$\begin{array}{l}\text { Overall score } \\
\text { (out of 12) }\end{array}$} \\
\hline & $\begin{array}{l}\text { Hunting in Indigenous } \\
\text { Lands (HIL) }\end{array}$ & $\begin{array}{c}\text { Biodiversity and Natural } \\
\text { Resources Monitoring Use } \\
\text { Program of Amazonas Protected } \\
\text { Areas (ProBUC) }\end{array}$ & $\begin{array}{l}\text { Fauna Monitoring } \\
\text { System of Mamirauá } \\
\text { Institute (SMUF) }\end{array}$ & $\begin{array}{l}\text { Event Book System } \\
\text { (EBS) }\end{array}$ & \\
\hline $\begin{array}{l}\text { Intensive participation in } \\
\text { monitoring phases }\end{array}$ & 3 & 3 & 1 & 3 & 10 \\
\hline $\begin{array}{l}\text { Selecting for } \\
\text { participants }\end{array}$ & 2 & 2 & 2 & 3 & 9 \\
\hline Paying for services & 1 & 1 & 3 & 2 & 7 \\
\hline $\begin{array}{l}\text { Information and results } \\
\text { feedback }\end{array}$ & 1 & 3 & 1 & 1 & 6 \\
\hline $\begin{array}{l}\text { Insertion in external } \\
\text { politics }\end{array}$ & 2 & 1 & 1 & 2 & 6 \\
\hline $\begin{array}{l}\text { Informing broader } \\
\text { policies }\end{array}$ & 1 & 1 & 1 & 2 & 5 \\
\hline $\begin{array}{l}\text { Linkage with education } \\
\text { programs }\end{array}$ & 3 & 1 & 1 & - & $5 \dagger$ \\
\hline $\begin{array}{l}\text { Marketing of monitored } \\
\text { resources }\end{array}$ & - & - & - & 3 & $3 \ddagger$ \\
\hline
\end{tabular}

general, more complex forms of empowerment such as community political or social empowerment were not frequently achieved compared to simpler forms of empowerment such as individual psychological. Although the systems were evaluated similarly in relation to their empowerment capacity, the facilitating processes differed given the existing conditions and strategies adopted by each monitoring system, which we discuss next.

\section{DISCUSSION}

\section{Conditions facilitating empowerment strategies in Brazil and Namibia}

\section{Value of biological resources}

The resources monitored were highly valued in the Namibian and Brazilian communities, either for subsistence or trade, which is a social-ecological aspect that increases the potential for local empowerment (Hockley et al. 2005). For instance, monitoring tradable resources in EBS had greater potential to promote economic and political empowerment than did monitoring nontradable resources. Conversely, subsistence game species in Amazonia are irreplaceable to some indigenous peoples because they are essential for social organization, cultural practices, and as a meat source (Kensinger 1983). The preoccupation with game resources, and the associated ecological knowledge, facilitated dialog between stakeholders and led to local empowerment. Although game is not the main meat source of some riverine communities, it contributes greatly to the nutrition of participants in ProBUC and SMUF because it is an important part of local culture.

\section{Rights to manage the resources}

Monitoring systems, even those not intending to empower locals, are less likely to be sustained if participants lack management rights (Danielsen et al. 2005). Established management rights create the security needed for empowerment through monitoring (Lawrence and Elphick 2002). In all four monitoring systems, communities had use rights guaranteed as a consequence of the establishment of sustainable use protected areas that allowed them to apply the monitoring results to management (Table 1). Although the land owned by the state cannot be traded, communities within it gain collective land and natural resource use rights.

In Brazil, for example, Indigenous Lands are titled to guarantee indigenous people social and cultural rights. These have exclusive rights over natural resource management for traditional use (Government of Brazil 1988), with conservation as an output (Stocks 2005). The government is responsible for guaranteeing protection to the people and their land. Management decisions in Indigenous Lands may involve other institutions such as governments, private companies, and NGOs if agreed upon by the indigenous people and the Federal Agency for Indigenous People. Conservancies in Namibia are created to allow communities to benefit from natural resources that they were restricted or prohibited from using during the apartheid regime. The legislation mandated that communities forming conservancies delineate the conservancy boundaries, 
Table 3. Scales and dimensions of local empowerment promoted through the use of monitoring systems in Brazilian Amazonia and Namibia. Numbers represent the authors' evaluation of local empowerment using a four-point scale, with 3 the highest and 0 the lowest degree of importance.

\begin{tabular}{|c|c|c|c|c|c|c|}
\hline \multirow[b]{2}{*}{ Monitoring system } & \multicolumn{2}{|c|}{ Scale of empowerment } & \multicolumn{4}{|c|}{ Dimension of empowerment } \\
\hline & Individual & Community & Psychological & Social & Political & Economic \\
\hline Hunting in Indigenous Lands (HIL) & 3 & 2 & 3 & 1 & 2 & 1 \\
\hline $\begin{array}{l}\text { Biodiversity and Natural Resources Monitoring Use } \\
\text { Program of Amazonas Protected Areas (ProBUC) }\end{array}$ & 3 & 2 & 3 & 2 & 1 & 1 \\
\hline $\begin{array}{l}\text { Fauna Monitoring System of Mamirauá Institute } \\
\text { (SMUF) }\end{array}$ & 2 & 1 & 2 & 1 & 1 & 2 \\
\hline Event Book System (EBS) & 3 & 2 & 3 & 1 & 2 & 3 \\
\hline Overall score (out of 12) & 11 & 7 & 11 & 5 & 6 & 7 \\
\hline
\end{tabular}

define membership, elect a committee, and design rules for the disbursement of benefits (Jones and Weaver 2009). The Namibian communities used EBS to adjust land-use management plans to mitigate human-wildlife conflicts and to lobby for increased access to wildlife, eventually resulting in the Ministry of Environment and Tourism allowing subsistence hunting in some conservancies.

\section{Political organization and leadership}

The community political organization and the presence of trusted leadership are key conditions that allow for sustainable monitoring systems and promote local empowerment (Danielsen et al. 2011). ProBUC and SMUF were implemented in communities that had participated in social organization movements motivated by the Catholic Church in the 1980s, culminating in Sustainable Development Reserve creation (Esterci and Schweickardt 2010). In Namibia, EBS originated in the 1980s from the development of a community game guard system in the Kunene Region of Namibia (Durbin et al. 1997). The presence of traditional authorities was instrumental to the development of the conservancy system and EBS implementation (Jones 1999). The involvement of community leaders was also crucial to the adoption of monitoring systems such as HIL and SMUF. In the case of ProBUC and EBS, supportive leaders communicated with external institutions that recognized the monitoring systems, drawing attention to the systems, which eventually informed regional policies. Communities with prior experience negotiating in local or regional political arenas, with organized systems of representation and accountability, enjoyed greater success in influencing external decisions, thereby securing better empowerment outcomes (Hoefle 2000).

\section{Collaboration between stakeholders}

Empowerment is facilitated by the interest of external institutions in decentralization and improving livelihoods through monitoring (Danielsen et al. 2011). The donors and lead institutions recognized the importance of local ecological knowledge and participation for motivating collaborative conservation practices. Governments permitted communities to manage their own natural resources, and NGOs often facilitated communication between the communities and government and lent support for implementation of management and in sustaining the natural resources. Prior collaboration between communities and external institutions forged mutual respect and trust, consolidated long-term work plans, and enhanced technical and political support for communities, thereby facilitating empowerment. For example, when monitoring began in Acre, the Comissão PróÍndio do Acre had already had a 10-year relationship with the monitors' communities. The government of Acre played an important role in supporting forest dwellers' empowerment (Kainer et al. 2003) and in recognizing the monitors as extension agents (Little 2005). ProBUC was implemented in communities with which the Amazonas state government Center for Protected Areas and partner NGOs collaborated in other initiatives. For EBS, the previous game guard system and collaboration between communities, the Ministry of Environment and Tourism, and NGOs was instrumental in its implementation.

\section{Monitoring systems strategies and local empowerment}

\section{Intensifying local participation}

There is potential for local empowerment through participation in various stages of a monitoring system, from design to implementation and evaluation (Danielsen et al. 2009). Individuals involved in data collection in all four monitoring systems were psychologically empowered, feeling proud to engage in a program with external researchers, learn new techniques, and promote resource stewardship. Monitors view themselves as respected by other members of the community. Three monitoring systems were innovative in intensifying local participation by promoting individual and community influence in the many monitoring phases (Evans and Guariguata 2008). In HIL and EBS there was participation in design, data collection, analysis, and interpretation; in ProBUC, participation occurred in design, data collection, interpretation, and system evaluation. Moreover, monitors represented their communities in negotiations with external 
actors, which enhanced their individual political and social power. Participation in data analysis and interpretation was particularly relevant to psychological and social community empowerment because some communities used the understanding of resource trends, together with other factors, to make management decisions (see Stuart-Hill et al. 2006 for the EBS experience).

\section{Linking monitoring to education, social learning, and capacity building}

Adult education and social learning are instruments for empowerment (Diduck 1999, Pound et al. 2005) and were tied to biological resource monitoring systems that developed individual skills and community organization (Evans and Guariguata 2008, Cundill and Fabricius 2009). HIL empowered monitors both psychologically and socially because it was incorporated into the indigenous education program, which was designed to promote citizenship through indigenous control of shared traditional and scientific knowledge (Monte 2000, Little 2005). The integration in the education program guaranteed continuity of training and monitoring linked to broader cognitive domains. The monitors, in turn, used the monitoring in their community schools to teach subjects such as math, ecology, and indigenous language, which promoted community empowerment. This framework did not initially guarantee information quality, but maintained the program's empowerment objective. Education was not the focus of ProBUC, SMUF, and EBS, but the training of monitors and other representatives developed individual skills such as literacy and numeracy (Stuart-Hill et al. 2006). An important aspect of ProBUC and EBS was that monitors could learn from one another and improve their skills over time because similar data were collected by several people.

\section{Access to information and results}

Dissemination of monitoring results was used by all systems to empower individuals and communities both psychologically and socially. Access to information enhances transparency and potentially empowers resource users politically if they are able to organize and apply the information (Chambers 2007). The dissemination meetings led by ProBUC and SMUF promoted institutional strengthening and community political empowerment through interpreting results, evaluating the systems, and improving management. Meetings also allowed other community members to recognize and acknowledge monitors' work, developing individual pride and self-esteem. In Namibia, this strategy was adopted, but the empowerment capacity was limited because community members seldom had access to EBS results because of inadequate dissemination of information. Although the data are freely available to the communities within the conservancy, they might not be aware of this and thus might only get EBS results at the annual general meeting.

\section{Selecting participants}

Intentional selection of participants is a common strategy in monitoring programs in other continents, promoting psychological and social empowerment to locally marginalized people (Garnett et al. 2009). The monitoring cases used two alternatives to select participants, which allowed individual psychological and social empowerment. In HIL, SMUF, and EBS, communities were responsible for selecting participants. Although this approach respected social-cultural relationships, there was the risk of reinforcing the social power of prominent members if they were favored over others. These individuals often leveraged their social standing to mobilize more people and negotiate more effectively with external groups. Women participated in SMUF and EBS, but not in HIL, reflecting strong gender divisions in indigenous labor. ProBUC intentionally encouraged the participation of women, elders, and illiterate members as monitors as a way to acknowledge internally marginalized groups and alleviate social inequality.

\section{Paying for monitoring services}

In EBS, the supporting NGOs initially paid monitors until wildlife management generated enough profits that conservancies could afford the monitors' salaries. In the Amazonian cases, monitors were paid using external funds. Instituto de Desenvolvimento Sustentável Mamirauá employed SMUF monitors as part of their research institute team, which increased local empowerment (Garnett et al. 2009). In ProBUC, monitors' labor compensation depended on projects approved by the Center for Protected Areas. In HIL, monitors received scholarships from an agreement with the state government. Paying for monitoring services in the four systems promoted economic empowerment at the individual scale, which was closely related to psychological, social, and political empowerment. While monitors could improve their livelihoods with the added income, individual funds were not systematically applied to benefit the community as a whole. Therefore, such payments rarely created community empowerment.

\section{Marketing monitored resources}

Only EBS was linked to rights to trade monitored resources, economically empowering individuals participating in the monitoring. Community members not participating in monitoring had the opportunity to benefit from the economic activity within the conservancy, including money and meat from safari hunting, and profits from craft-making. Economic empowerment in conservancies resulted in individual psychological and social empowerment given their capacity to pursue goods, as in other community-based management programs (DeCaro and Stokes 2008). In Brazil, no monitored resource in the studied systems was marketed because commercial game use is illegal in these protected areas. Nevertheless, the awareness of political efforts to allow for commercial wildlife harvest under controlled management in 
Brazil motivated local participation, based on experiences of legally marketing monitored resources in Amazonia such as the Arapaima gigas fish in Brazil (Castello et al. 2009) and peccaries (Tayassu sp.) in Peru (Fang et al. 2008), which economically empowered individuals and communities.

\section{Informing regional policy and insertion into regional politics}

Although participatory monitoring tends to be limited to local management (Danielsen et al. 2011), there are examples of these systems informing regional policy. Fry (2011) illustrates how community empowerment at the political and social dimensions are influenced by the way monitoring systems inform regional policy. EBS influenced the setting of conservancy hunting quotas, influenced national and international policy on the sale of ivory stockpiles, contributed toward the Human-Animal Conflict Self-Insurance Scheme (HACSIS), and motivated replication of the monitoring program in national parks (Stuart-Hill et al. 2006). Through government recognition of these systems, local communities were politically empowered (Stuart-Hill et al. 2006). HIL oriented state conservation policy for indigenous lands through the institutional arrangements between the supporting NGO, researchers, and regional governments (Chaves et al. 2012). Although ProBUC did not intend to produce a regional data set, the methods have been replicated in monitoring initiatives throughout Amazonia. Monitoring also facilitated local peoples' insertion into the political arena. Monitors represented local communities in debates on large-scale monitoring methodologies (e.g., Amazonia Protected Areas Program in Brazil), local empowerment, and community participation (IX International Congress on Wildlife Management in Amazonia, http://www.ixcimfauna-bol. museonoelkempff.org). ProBUC's Médio Juruá River Ecological Games inserted community members into municipal-level conservation and development negotiations, which resulted in the allocation of funds for monitoring, politically empowering communities in Amazonia.

\section{CONCLUSIONS}

\section{Learning from monitoring systems in Latin America and southern Africa}

Through this research, we have identified coincident empowerment outcomes that are related to similar strategies adopted in both continents. For example, HIL and ProBUC staff, in seeking to design a lasting monitoring system with relevance to local people, purposefully adapted some of the EBS principles after sharing experiences with people involved in wildlife management in Africa and accessing EBS publications (e.g., data collection, analysis, and reporting are performed locally, with external staff as facilitators of local processes). Additionally, individual and psychological empowerment are the most common forms achieved through monitoring system participation, consistent with Garnett et al. 's (2009) conclusions. More complex forms of empowerment (e.g., community political) were rarer and were independent of continent because they appeared to be more context specific.

The most obvious difference between the Brazilian and Namibian contexts was observed in terms of resource market value. This was related to the limitations and opportunities imposed when the systems were implemented. In Namibia, wildlife and associate services have high financial value, so governments and communities have a vested interest in maintaining the benefits of this wildlife. Legislation allows for marketing of this valuable resource in Namibian conservancies, conditioned upon the community's capacity to manage it. The creation of economically and ecologically sustainable practices that promote economic empowerment to people with subsistence use rights over resources remains a challenge in Amazonia (Hall 2007). Sustainable wildlife management could be achieved if commercial trade focuses on local and regional markets, the communities are involved in management, and an adequate monitoring system is in place, among other conditions (da Silveira 2011). The ban on wildlife trade for preservation in Brazil relies on obsolete legislation (da Silveira 2011); because communities are already involved in monitoring systems, the wildlife commerce debate in Amazonia could benefit from the experience in Namibia to improve community economic empowerment.

We also recognize differences in standardization in Brazil and Namibia. Namibia created a nation-wide replicable participatory monitoring system with standardized methods and organization, controlled by the conservancy committees. This standardization makes it more amenable to scaling up information, which has the potential to advise large-scale policy. In Brazil, large-scale systems are implemented that are focused more on ecological conservation research, with locals only involved to reduce costs and increase efficiency (Magnusson et al. 2008). Although the institutionalization process with empowerment outcomes occurring in Namibia may be context specific, Latin American conservationists should be aware of the EBS mechanisms for scaling up information. In so doing, the monitoring systems could better promote community, social, and political empowerment.

A potential consequence of large-scale monitoring systems is the challenge of transferring information to the entire community (Danielsen et al. 2010b). This is perhaps the biggest challenge facing EBS. Although the conservancy committees control the monitoring system, which facilitates community empowerment, the information seems to be retained at this scale, which can contribute to community inequality (Schiffer 2004). By contrast, the participatory monitoring systems in Amazonia intensively return information and results to the individual scale, transferring decision power to individuals. The integration of the 
monitoring system into an education program, as in HIL in Acre, would be an alternative to disseminate information, as well as to enhance psychological and social empowerment. It is important to note that the case of HIL is unique because of the 30-year Comissão Pró-Índio do Acre know-how with indigenous education and the long-term relationship with communities, experience that is uncommon in Amazonia.

\section{Challenges and limitations of community-based monitoring}

Empowerment through participatory monitoring promoted greater local autonomy in resource management and challenged institutional power relationships. Some strategies were purposefully selected to promote empowerment, whereas others were adapted secondarily or had empowerment as an unexpected outcome. For example, SMUF was based on the existing community political organization to adapt the system and promote local empowerment, yet it had limited impact on social and political dimensions. It should be noted that local empowerment may have implications contrary to the conservationist agenda (Sayer et al. 2005). Devolving management rights and information access does not guarantee that community decisions will reflect conservation goals (McIntosh and Renard 2010). Communities in Namibia and Amazonia shared management rights with the state based on the principle that conservation in protected areas should benefit the locals and larger society. In HIL and SMUF, however, communities occasionally rejected conservation management actions supported by monitoring data in favor of political decisions that were more consistent with the communities' development interests.

Another major challenge of biological resource participatory monitoring systems is their maintenance over the long term, especially if they are vulnerable to funding uncertainty. Systems that promote empowerment are expected to last longer given local interest in continuing these programs (Danielsen et al. 2005). The main strategies adopted in EBS and HIL, i.e., marketing the monitored resource and integrating the system into an education program, respectively, continued beyond the initial funding available because communities realized benefits from these systems. Using multiple strategies to achieve diverse empowerment dimensions, however, increases costs to outsiders and to locals from the onset (Garcia and Lescuyer 2008), whereas benefits may not be promptly realized. Monitoring, therefore, becomes an expense for everyone and may fail before inciting significant social transformations. Moreover, empowerment mechanisms may become obsolete because communities experience institutional transformations, new group dynamics, and evolving interests, which force the system to adapt constantly.

This research explores the many scales and dimensions of empowerment to which community-based monitoring systems contribute. We illustrate the facilitating conditions that lead to these empowerment outcomes and the strategies employed to allow them. We also identify weaknesses in the Latin American and Namibian contexts and, in so doing, suggest improvements that enhance the potential for local empowerment. Further scientific effort using a similar framework should be made to capture and evaluate individual and collective perceptions of local empowerment through the monitoring of biological resources. Although empowerment may not be the primary goal of many community-based monitoring systems, the systems must be carefully planned, taking advantage of local and regional facilitating conditions, and must respect community positions to improve dialog in the democratization process. The outcomes of local empowerment should not be ignored because they can be used effectively as a tool to engage communities in natural resource management, and ultimately lead to the persistence of these monitoring systems in the long term.

Responses to this article can be read online at: http://www.ecologyandsociety.org/issues/responses. $\mathrm{php} / 5164$

\section{Acknowledgments:}

We thank the communities of Indigenous Lands in Acre; M, édio Juruá, RDS Amanã, and Mamirauá in Amazonas; and conservancies in Namibia. The Comissão Pró-Índio do Acre, Instituto de Desenvolvimento Sustentável Mamirauá, and Centro Estadual de Unidades de Conservação do Amazonas lead the monitoring systems and supported this paper. The Gordon and Betty Moore Foundation, The Nature Conservancy, DANIDA, and the monitoring matters network provided financial support. J. M. V. Fragoso, L. Castello, G. Miranda, A. Kaxinawa, F. Kaxinawa, A. F. Silva, M. F. Carmo, and A. A. Gondim participated in the symposium "Monitoramento participativo: uma ferramenta para empoderamento comunitário" at the IX CIMFAUNA conference. We also thank all UF/TCD students and researchers for their assistance, as well as two anonymous reviewers who provided important contributions to the manuscript.

\section{LITERATURE CITED}

Amaral, J. V. 2005. Diversidade de mamíferos e uso da fauna nas Reservas de Desenvolvimento Sutentável Mamirauá e Amanã - Amazônas - Brasil. Thesis. Museu Paraense Emílio Goeldi and Universidade Federal do Pará, Belem, Brazil. [online] URL: http://www.academia.edu/1214189/DIVERSIDADE DE MAMIFEROS E USO DA FAUNA NAS RESERVAS DE DESENVOLVIMENTO_SUSTENTAVEL MAMIRAUA_E_AMANA _ _AMAZONAS _-_BRASIL. 
Andrade, P. C. M., J. R. S. Pinto, A. C. Lima, J. A. M. Duarte, P. M. Costa, P. H. G. Oliveira, and S. H. Azevedo. 2005. Projeto Pé de Pincha: parceria de futuro para conservar quelônios aquáticos na várzea amazônica. IBAMA, Provárzea, Brazil.

Arnstein, S. R. 1969. A ladder of citizen participation. Journal of the American Institute of Planners 35(4):216-224. http:// dx.doi.org/10.1080/019443666908977225

Brown, K. 2002. Innovations for conservation and development. Geographical Journal 168(1):6-17. http://dx. doi.org/10.1111/1475-4959.00034

Castello, L., J. P. Viana, G. Watkins, M. Pinedo-Vasquez, and V. A. Luzadis. 2009. Lessons from integrating fishers of Arapaima in small-scale fisheries management at the Mamirauá Reserve, Amazon. Environmental Management 43 (2):197-209. http://dx.doi.org/10.1007/s00267-008-9220-5

Chambers, R. 2007. Who counts? The quiet revolution of participation and numbers. Working Paper 296. Institute of Development Studies, Brighton, UK. [online] URL: http:// www.ids.ac.uk/files/Wp296.pdf.

Chaves, W., F. P. C. Silva, P. A. L. Constantino, and P. M. Drumond. 2012. A caça no estado do Acre. In Governo do Estado do Acre, editor. Uso dos recursos naturais e da fauna. Programa estadual de zoneamento ecológico-econômico do Estado do Acre, II fase. SEMA, Rio Branco, Brazil, in press.

Constantino, P. A. L. 2010. Disentangling the effects of deforestation and indigenous hunting on wildlife in the Amazon. Thesis. University of Florida, Gainesville, Florida, USA. [online] URL: http://www.ibcperu.org/doc/isis/14446. pdf.

Constantino, P. A. L., L. B. Fortini, F. R. S. Kaxinawa, A. M. Kaxinawa, E. S. Kaxinawa, A. P. Kaxinawa, L. S. Kaxinawa, J. M. Kaxinawa, and J. P. Kaxinawa. 2008. Indigenous collaborative research for wildlife management in Amazonia: the case of the Kaxinawá, Acre, Brazil. Biological Conservation 141(11):2718-2729. http://dx.doi.org/10.1016/ j.biocon.2008.08.008

Cundill, G., and C. Fabricius. 2009. Monitoring in adaptive co-management: toward a learning based approach. Journal of Environmental Management 90(11):3205-3211. http://dx. doi.org/10.1016/j.jenvman.2009.05.012

Da Silveira, R. 2011. Management of wildlife in the foodplain: a critical look at threats, bottlenecks and the future in Amazonia. Pages 137-144 in M. Pinedo-Vasquez, M. L. Ruffino, C. Padoch, and E. S. Brondízio, editors. The Amazon varzea: the decade past and the decade ahead. Springer, New York, New York, USA.
Danielsen, F., N. D. Burgess, and A. Balmford. 2005. Monitoring matters: examining the potential of locally-based approaches. Biodiversity and Conservation 14(11):2507-2542. http://dx.doi.org/10.1007/s10531-005-8375-0

Danielsen, F., N. D. Burgess, A. Balmford, P. F. Donald, M. Funder, J. P. G. Jones, P. Alviola, D. S. Balete, T. Blomley, J. Brashares, B. Child, M. Enghoff, J. Fjeldså, S. Holt, H. Hübertz, A. E. Jensen, P. M. Jensen, J. Massao, M. M. Mendoza, Y. Ngaga, M. K. Poulsen, R. Rueda, M. Sam, T. Skielboe, G. Stuart-Hill, E. Topp-Jørgensen, and D. Yonten. 2009. Local participation in natural resource monitoring: a characterization of approaches. Conservation Biology 23 (1):31-42. http://dx.doi.org/10.1111/j.1523-1739.2008.01063. $\underline{\mathrm{X}}$

Danielsen, F., N. Burgess, M. Funder, T. Blomley, J. Brashares, A. Akida, A. Jensen, M. Mendoza, G. Stuart-Hill, M. K. Poulsen, H. Ramadhani, M. K. Sam, and E. ToppJørgensen. 2010a. Taking stock of nature in species-rich but economically poor areas: an emerging discipline of locally based monitoring. Pages 89-112 in A. Lawrence, editor. Taking stock of nature: participatory biodiversity assessment for policy, planning and practice. Cambridge University Press, Cambridge, UK.

Danielsen, F., N. D. Burgess, P. M. Jensen, and K. PirhoferWalzl. 2010b. Environmental monitoring: the scale and speed of implementation varies according to the degree of peoples involvement. Journal of Applied Ecology 47(6):1166-1168. http://dx.doi.org/10.1111/j.1365-2664.2010.01874.x

Danielsen, F., M. M. Mendoza, P. Alviola, D. S. Balete, M. Enghoff, M. K. Poulsen, and A. E. Jensen. 2003. Biodiversity monitoring in developing countries: What are we trying to achieve? Oryx 37(4):407-409. http://dx.doi.org/10.1017/ $\underline{\text { S0030605303000735 }}$

Danielsen F., M. Skutsch, N. D. Burgess, P. M. Jensen, H. Andrianandrasana, B. Karky, R. Lewis, J. C. Lovett, J. Massao, Y. Ngaga, P. Phartiyal, M. K. Poulsen, S. P. Singh, S. Solis, M. Sørensen, A. Tewari, R. Young, and E. Zahabu. 2011. At the heart of REDD+: a role for local people in monitoring forests? Conservation Letters 4(2):158-167. http://dx.doi. org/10.1111/j.1755-263X.2010.00159.X

DeCaro, D., and M. Stokes. 2008. Social-psychological principles of community-based conservation and conservancy motivation: attaining goals within an autonomy-supportive environment. Conservation Biology 22(6):1443-1451. http:// dx.doi.org/10.1111/j.1523-1739.2008.00996.x

Diduck, A. 1999. Critical education in resource and environmental management: learning and empowerment for a sustainable future. Journal of Environmental Management 57(2):85-97. http://dx.doi.org/10.1006/jema.1999.0289 
Durbin, J., B. Jones, and M. Murphree. 1997. Namibian community-based natural resource management programme. Project Evaluation. Worldwide Fund for Nature, Gland, Switzerland.

Esterci, N., and K. H. S. C. Schweickardt. 2010. Territórios amazônicos de reforma agrária e de conservação da natureza. Boletim do Museu Paraense Emilio Goeldi 5(1):59-77. http:// dx.doi.org/10.1590/S1981-81222010000100006

Evans, K., and M. R. Guariguata. 2008. Participatory monitoring in tropical forest management: a review of tools, concepts and lessons learned. CIFOR, Bogor, Indonesia. [online] URL: http://www.cifor.org/online-library/browse/ view-publication/publication/2486.html.

Eyben, R., C. Harris, and J. Pettit. 2006. Introduction: exploring power for change. IDS Bulletin 37(6):1-10. http:// dx.doi.org/10.1111/j.1759-5436.2006.tb00318.x

Fa, J.E., and D. Brown. 2009. Impacts of hunting on mammals in African tropical moist forests: a review and synthesis. Mammal Review 39(4):231-264. http://dx.doi.org/10.1111/ j.1365-2907.2009.00149.x

Fang, T. G., R. E. Bodmer, P. E. Puertas, P. M. Aparicio, P. P. Peña, R. A. Villanes, and D. T. S. Hayman. 2008. Certificación de pieles de pecaríes en la Amazonía Peruana: una estratégia para la conservación y manejo de fauna silvestre en la Amazonía Peruana. Wust Ediciones, Lima, Peru. [online] URL: http://www.kent.ac.uk/dice/research/ peccary/Fang et al 08 certificacion.pdf.

Ferraz, G., C. E. Marinelli, and T. E. Lovejoy. 2008. Biological monitoring in the Amazon: recent progress and future needs. Biotropica 40(1):7-10. http://dx.doi.org/10.1111/ j.1744-7429.2007.00355.x

Fonseca Junior, S. F., C. E. Marinelli, H. S. A. Carlos, J. R. Weigand, R. B. Fernandes, J. V. C. Silva, M. C. Silva, P. F. Lemos, and D. Calandino. 2011. Programa de Monitoramento da Biodiversidade e do Uso de Recursos Naturais - ProBUC: a experiência das unidades de conservação estaduais do Amazonas. Centro Estadual de Unidades de Conservação, Manaus, Brazil.

Fry, B. P. 2011. Community forest monitoring in REDD+: the ' $\mathrm{M}$ ' in MRV? Environmental Science and Policy 14 (2):181-187. http://dx.doi.org/10.1016/j.envsci.2010.12.004

Garcia, C. A., and G. Lescuyer. 2008. Monitoring, indicators and community based forest management in the tropics: pretexts or red herrings? Biodiversity and Conservation 17 (6):1303-1317. http://dx.doi.org/10.1007/s10531-008-9347ע

Garnett, S. T., G. M. Crowley, H. Hunter-Xenie, W. Kozanayi, B. Sithole, C. Palmer, R. Southgate, and K. K. Zander. 2009. Transformative knowledge transfer through empowering and paying community researchers. Biotropica 41(5):571-577. http://dx.doi.org/10.1111/j.1744-7429.2009.00558.x

Government of Brazil. 1988. Constituição Federativa do Brasil. Presidência da República, Casa Civil, Brazil.

Hall, A. 2007. Extractive reserves: building natural assets in the Brazilian Amazon. Pages 151-180 in J. K. Boyce, S. Narain, and E. A. Stanton, editors. Reclaiming nature: environmental justice and ecological restoration. Anthem Press, London, UK. http://dx.doi.org/10.7135/ $\underline{\mathrm{UPO} 9781843313465.007}$

Hockley, N. J., J. P. G. Jones, F. B. Andriahajaina, A. Manica, E. H. Ranambitsoa, and J. A. Randriamboahary. 2005. When should communities and conservationists monitor exploited resources? Biodiversity and Conservation 14(11):2795-2806. http://dx.doi.org/10.1007/s10531-005-8416-8

Hoefle, S. W. 2000. Patronage and empowerment in the central Amazon. Bulletin of Latin American Research 19(4):479-499. http://dx.doi.org/10.1111/j.1470-9856.2000.tb00120.x

Jerozolimski, A., and C. A. Peres. 2003. Bringing home the biggest bacon: a cross-site analysis of the structure of hunterkill profiles in Neotropical forests. Biological Conservation 111(3):415-425. http://dx.doi.org/10.1016/S0006-3207(02) $00310-5$

Jones, B. T. B. 1999. Policy lessons from the evolution of a community-based approach to wildlife management, Kunene Region, Namibia. Journal of International Development 11 (2):295-304. http://dx.doi.org/10.1002/(SICI)1099-1328(199903/04) 11:2<295::AID-JID583>3.0.CO;2-U

Jones, B., and M. Murphree. 2001. The evolution of policy on community conservation in Namibia and Zimbabwe. Pages 38-58 in D. Hulme and M. W. Murphree, editors. African wildlife and livelihoods: the promise and performance of community conservation. James Currey, Oxford, UK.

Jones, B., and L. C. Weaver. 2009. CBNRM in Namibia: growth, trends, lessons and constraints. Pages 223-242 in $\mathrm{H}$. Suich, B. Child, and A. Spenceley, editors. Evolution and innovation in wildlife conservation: park and game ranches to transfrontier conservation areas. Earthscan, London, UK.

Kainer, K. A., M. Schmink, A. C. P. Leite, and M. J. S. Fadell. 2003. Experiments in forest-based development in western Amazonia. Society and Natural Resources 16(10):869-886. http://dx.doi.org/10.1080/716100619

Kapoor, I. 2002. The devil's in the theory: a critical assessment of Robert Chambers' work on participatory development. Third World Quarterly 23(1):101-117. http://dx.doi. org/10.1080/01436590220108199

Kensinger, K. M. 1983. On meat and hunting. Current Anthropology 24(1):128-129. http://dx.doi.org/10.1086/202957 
Kilbane Gockel, C., and L. C. Gray. 2009. Integrating conservation and development in the Peruvian Amazon. Ecology and Society 14(2): 11. [online] URL: http://www. ecologyandsociety.org/vol14/iss2/art11/.

Larson, A. M., and F. Soto. 2008. Decentralization of natural resource governance regimes. Annual Review of Environment and Resources 33:213-239. http://dx.doi.org/10.1146/ annurev.environ.33.020607.095522

Lawrence, A. 2006. "No personal motive?" Volunteers, biodiversity, and the false dichotomies of participation. Ethics, Place \& Environment 9(3):279-298. http://dx.doi. org/10.1080/13668790600893319

Lawrence, A., and M. Elphick, editors. 2002. Policy implications of participatory biodiversity assessment: ETFRN international seminar for policy-makers and implementers. Summary report. Environmental Change Institute, Oxford, UK. [online] URL: http://www.dfid.gov.uk/r4d/PDF/ Outputs/Forestry/R7475__Policy_Implications_PAMEB_1. pdf.

Lawrence, A., K. Paudel, R. Barnes, and Y. Malla. 2006. Adaptive value of participatory biodiversity monitoring in community forestry. Environmental Conservation 33 (4):325-334. http://dx.doi.org/10.1017/S0376892906003432

Lele, S., P. Wilshusen, D. Brockington, R. Seidler, and K. Bawa. 2010. Beyond exclusion: alternative approaches to biodiversity conservation in the developing tropics. Current Opinion in Environmental Sustainability 2(1-2):94-100. http://dx.doi.org/10.1016/j.cosust.2010.03.006

Lindenmayer, D. B., and G. E. Likens. 2010. The science and application of ecological monitoring. Biological Conservation 143(6):1317-1328. http://dx.doi.org/10.1016/j.biocon.2010.02.013

Little, P. E. 2005. Indigenous peoples and sustainable development subprojects in Brazilian Amazonia: the challenges of interculturality. Law and Policy 27(3):450-471. http://dx.doi.org/10.1111/j.1467-9930.2005.00207.x

Luttrel, C., S. Quiroz, C. Scrutton, and K. Bird. 2009. Understanding and operationalising empowerment. Working Paper 308. Overseas Development Institute, London, UK. [online] URL: http://www.odi.org.uk/resources/docs/5500. pdf.

Magnusson, W. E., F. Costa, A. Lima, F. Baccaro, R. BragaNeto, R. L. Romero, M. Menin, J. Penha, J.-M. Hero, and B. E. Lawson. 2008. A program for monitoring biological diversity in the Amazon: an alternative perspective to threatbased monitoring. Biotropica 40(4):409-411. http://dx.doi. org/10.1111/j.1744-7429.2008.00427.x

Marinelli, C. E., H. S. A. Carlos, R. F. Batista, F. Rohe, F. Waldez, T. P. Kasecker, W. Endo, and R. F. Godoy. 2007.
Programa de Monitoramento da Biodiversidade e do Uso de Recursos Naturais - ProBUC. Revista Áreas Protegidas da Amazônia 1:73-78.

Maton, K. I. 2008. Empowering community settings: agents of individual development, community betterment, and positive social change. American Journal of Community Psychology 41(1-2):4-21. http://dx.doi.org/10.1007/ s10464-007-9148-6

McIntosh, S., and Y. Renard. 2010. Placing the commons at the heart of community development: three case studies of community enterprise in Caribbean islands. International Journal of the Commons 4(1):160-182.

Moller, H., F. Berkes, P. O. Lyver, and M. Kislalioglu. 2004. Combining science and traditional ecological knowledge: monitoring populations for co-management. Ecology and Society 9(3): 2. [online] URL: http://www.ecologyandsociety. org/vol9/iss3/art2/.

Monte, N. L. 2000. The others, who we are? Training indigenous teachers and intercultural identities. Caderno de Pesquisa 111:7-29. http://dx.doi.org/10.1590/ $\underline{\mathrm{S} 0100-15742000000300001}$

Peres, C. A. 2000. Effects of subsistence hunting on vertebrate community structure in Amazonian forests. Conservation Biology 14(1):240-253. http://dx.doi.org/10.1046/ j.1523-1739.2000.98485.x

Pound, B., S. Snapp, C. McDougall, and A. Braun, editors. 2005. Managing natural resources for sustainable livelihoods: uniting science and participation. Earthscan, London, UK. [online] URL: http://www.ibcperu.org/doc/ isis/5601.pdf.

Rappaport, J. 1987. Terms of empowerment/exemplars of prevention: toward a theory for community psychology. American Journal of Community Psychology 15(2):121-148.

Rijsoort, J., and Z. Jinfeng. 2005. Participatory resource monitoring as a means for promoting social change in Yunnan, China. Biodiversity and Conservation 14(11):2543-2573. http://dx.doi.org/10.1007/s10531-005-8377-y

Rist, J., E. J. Milner-Gulland, G. Cowlishaw, and M. Rowcliffe. 2010. Hunter reporting of catch per unit effort as a monitoring tool in a bushmeat-harvesting system. Conservation Biology 24(2):489-499. http://dx.doi.org/10.1111/ j.1523-1739.2010.01470.x

Rocha, E. M. 1997. A ladder of empowerment. Journal of Planning Education and Research 17(1):31-44. http://dx.doi. org/10.1177/0739456X9701700104

Rostant, L. V. R. 2011. The efficacy of community-based monitoring in Namibia, the event book system. Dissertation. University of Florida, Gainesville, Florida, USA. 
Saegert, S., and G. Winkel. 1996. Paths to community empowerment: organizing at home. American Journal of Community Psychology 24(4):517-550. http://dx.doi.org/10.1007/ BF02506795

Samah, A. A., and F. Aref. 2011. The theoretical and conceptual framework and application of community empowerment and participation in processes of community development in Malaysia. Journal of American Science 7 (2):186-195.

Sayer, J., C. Elliott, E. Barrow, S. Gretzinger, S. Maginnis, T. McShane, and G. Shepherd. 2005. Implications for biodiversity conservation of decentralized forest resources management. Pages 121-138 in C. J. Pierce Colfer and D. Capistrano, editors. The politics of decentralization: forests, power and people. Earthscan, London, UK.

Schiffer, E. 2004. How does community-based natural resource management in Namibia change the distribution of power and influence? Preliminary findings. DEA Research Discussion Paper 67. Ministry of Environment and Tourism, Windhoek, Namibia. [online] URL: http://www.drfn.info:85/ pdf/RDP67.pdf.

Scholes, R. J., G. M. Mace, W. Turner, G. N. Geller, N. Jürgens, A. Larigauderie, D. Muchoney, B. A. Walther, and H. A. Mooney. 2008. Toward a global biodiversity observing system. Science 321:1044-1045. http://dx.doi.org/10.1126/ science. 1162055

Sofield, T. H. B. 2003. Empowerment for sustainable tourism development. Elsevier, Oxford, UK.

Speer, P. W., and J. Hughey. 1995. Community organizing: an ecological route to empowerment and power. American Journal of Community Psychology 23(5):729-748. http://dx. doi.org/10.1007/BF02506989

Stocks, A. 2005. Too much for too few: problems of indigenous land rights in Latin America. Annual Review of Anthropology 34:85-104. http://dx.doi.org/10.1146/annurev. anthro.33.070203.143844

Stringer, L. C., A. J. Dougill, E. Fraser, K. Hubacek, C. Prell, and M. S. Reed. 2006. Unpacking "participation" in the adaptive management of social-ecological systems: a critical review. Ecology and Society 11(2): 39. [online] URL: http:// www.ecologyandsociety.org/vol11/iss2/art39/.

Stuart-Hill, G., R. Diggle, B. Munali, J. Tagg, and D. Ward. 2005. The event book system: a community-based natural resource monitoring system from Namibia. Biodiversity and Conservation 14(11):2611-2631. http://dx.doi.org/10.1007/ s10531-005-8391-0

Stuart-Hill, G., R. Diggle, B. Munali, J. Tagg, and D. Ward. 2006. The event book system: community-based monitoring in Namibia. Participatory Learning and Action 55(1):70-78.
United Nations Environment Program. 2001. Participatory mechanisms for indigenous and local communities. Note by Executive Secretariat, Convention on Biological Diversity, Montreal, Canada. [online] URL: http://www.cbd.int/doc/ meetings/tk/wg8j-05/official/wg8j-05-05-en.pdf.

Valsecchi, J. 2012. Caça de animais silvestres nas Reservas de Desenvolvimento Sustentável Mamirauá e Amanã. Dissertation. Federal University of Minas Gerais, Belo Horizonte, Brazil.

Valsecchi, J., and P. V. Amaral. 2009. Perfil da caça e dos caçadores na Reserva de Desenvolvimento Sustentável Amanã, Amazônas - Brasil. Uakari 5(2):33-48.

Zimmerman, M. A., B. A. Israel., A. Schultz, and B. Checkoway. 1992. Further explorations in empowerment theory: an empirical analysis of psychological empowerment. American Journal of Community Psychology 20(6):707-727. http://dx.doi.org/10.1007/BF01312604 